\title{
Quantifying predation pressure along an urbanisation gradient in Denmark using artificial caterpillars
}

\author{
Marco FERRANTE ${ }^{1}$, Alessandro LO CACCIATO ${ }^{2}$ and Gabor L. LÖVEI ${ }^{1}$ \\ ${ }^{1}$ Aarhus University, Department of Agroecology, Flakkebjerg Research Centre, Forgøsvej 1, DK-4200 Slagelse, Denmark; \\ e-mails: marco.ferrante@agrsci.dk; gabor.lovei@agrsci.dk \\ ${ }^{2}$ University of Palermo, Faculty of Science, Via Archirafi 28, 90123 Palermo, Italy; e-mail: locacciato-alessandro@live.it
}

Key words. Carabidae, Formicidae, fragmentation, natural enemies, ecosystem services, predation, urbanisation, sentinel prey

\begin{abstract}
Urbanisation results in a marked modification of habitats and influences several ecological processes, some of which give rise to beneficial ecological services. Natural pest control, the effect of predators on prey is one of such services. We quantified changes in the incidence of predation with increasing levels of urbanisation using artificial caterpillars made of green plasticine. Potential predators can be identified by the "attack marks" they leave on these artificial caterpillars. We conducted this study from May to October 2010 around the city of Sorø (Zealand, Denmark), in forests along an urbanisation gradient (rural-suburban-urban). Artificial caterpillars were placed on the ground in order to obtain an estimate of the incidence of predation at ground level. Half (50\%) of the 1398 caterpillars were "attacked" and $28.8 \%$ of the bites were those of chewing insects. We attributed the majority of these to carabids, the most common group of ground-active arthropods. Chewing insects exerted the greatest predation pressure in the original forest (52.1\%), with lower values recorded in the suburban (10.1\%) and urban (16.4\%) forest fragments. Ants were responsible for only $4.7 \%$ of the attacks in forest, $11.3 \%$ in suburban and $16.4 \%$ in urban forest fragments. Mammals exerted the highest predation pressure in suburban habitats $(22.2 \%$ vs. $4.9 \%$ in forest, and $8.1 \%$ in urban forest fragments).
\end{abstract}

\section{INTRODUCTION}

\section{Ecological services}

Biodiversity provides several benefits, termed ecological or ecosystem services, which are essential for human survival (Millennium Ecosystem Assessment, 2005). The continued increase in the human population is accompanied by marked modifications of natural areas resulting in a reduction in biodiversity, which usually negatively affects the services provided (Carpenter et al., 2009). Urbanisation is a major cause of pollution, habitat loss, extinction and impoverished biodiversity through homogenization and invasions (McKinney, 2002). However, even if the consequences of these effects are known, the quantification of ecological services is difficult and changes in the numbers of useful organisms are often used as a proxy for the level of services they provide (Isbell et al., 2011). The relationship, however, is not necessarily straightforward, with additional, controversial aspects linked to sampling, rarity, intra-guild relationships and the selection of reliable indicators (Hilty \& Merenlender, 2000). Considering the environmental and economic importance of the well-being of ecosystem services for humans, it is important to identify and accurately measure ecosystem services (Layke et al., 2012; Liss et al., 2013).

\section{Predation}

Predation by natural enemies is one of the ecological services (de Groot et al., 2002), and changes in the composition and density of natural enemy groups (usually restricted to one or a few taxonomic categories) in response to urbanisation are numerous (Magura et al., 2010). However, assessing changes in the ecological function of pest control by natural enemies is neither common nor easy. Attacks by predators on invertebrate prey are usually cryptic and rarely leave any evidence, making its quantification difficult. Visual observation may be complicated, and even when possible, the presence of the observer may affect the activity of the predators. When other methods are used, such as examination of gut contents, or radioactive labelling of the prey, distinguishing between "real" predation and scavenging or secondary predation is difficult or impossible; the spread of the radioactive label may also be related to nonpredatory events (Kidd \& Jervis, 2007). One way of measuring predation intensity is to use sentinel prey (O'Neal et al., 2005), which relies on placing prey items in a habitat, and infers predation pressure from their rate of disappearance. Suitable prey are the immobile stages of insects such as eggs (Wilson et al., 2004) or pupae (Rowe et al., 2013), or immobilised insects (e.g. aphids glued on a card, Östman et al., 2001). The disadvantage of this method is that the prey usually disappears and the identity of the predator is rarely discernible. Dummy prey can also be used, which is not removed and the marks of the attempted predation can be used to identify the predator (Howe et al., 2009). While it is not usually possible to quantify predation intensity in this way (Brodie, 1993), it is useful for comparing predation pressure in various habitats (Howe et al., 2009). Studies often indicate a high predation pressure, especially in tropical habitats (Loiselle \& Farji-Brener, 2002; Posa et al., 2007; Howe et al., 2009), but there are few records from the temperate regions; published studies using dum- 
my prey usually focus on predation by birds (e.g. Mäntylä et al., 2008).

\section{Aims}

Urbanisation affects the diversity and density of various groups of predators, including birds (Chace \& Walsh, 2006), ground beetles (Magura et al., 2010) and spiders (Alaruikka et al., 2002; Horvath et al., 2012). However, it can only be speculated what the consequences of these structural changes on ecological functioning might be. In order to better understand the consequences of increasing urbanisation on the natural incidence of predation by ground active predators, we used the dummy caterpillar method (Howe et al., 2009) along an urbanisation gradient in Denmark. As natural habitats may offer better conditions (i.e. favourable temperature regimes, natural refuges) for predators we tested the hypothesis that the incidence of predation will diminish along a gradient of increasing urbanisation, with the highest rates recorded in forest, and lowest in patches of forest in urban parks, which corresponds to Gray's increasing disturbance hypothesis (Gray, 1989).

\section{MATERIAL AND METHODS}

\section{Study area}

Our study area was in and around the city of Sorø $\left(55^{\circ} 26^{\prime} \mathrm{N}\right.$; 1134'E; UTM: PG64), 80 km south-west of Copenhagen (Zealand, Denmark), along an urbanisation gradient selected according to the Globenet protocol (Elek \& Lövei, 2005). The urbanisation gradient included rural, suburban and urban areas, each of which originated from a primary forest of beech (Fagus sylvatica) and was characterized by an increasing built-up area (0\%-20\%-40\%) but no difference in soil characteristics (Howe \& Engaard, 2006). The rural area (160 ha) was ca. $3 \mathrm{~km}$ west of the town centre, bordered by Lake Sorø and almost completely dominated by beech, that persisted, although gradually decreasing in abundance in the other habitats. Small patches of pine (Pinus sylvestris) and other deciduous trees occurred near the forest roads. The seasonal understory of herbaceous plants consisted of Anemone silvestris, $A$. ranunculoides, and Leucojum vernum. The suburban area (30 ha) was originally a wet forest area, now under forestry management, and close to an old cemetery. The urban area (25 ha), located 4 $\mathrm{km}$ from the suburban area, was an isolated park adjacent to the lake visited by many people during the year. Here the incidence of beech was lower; other trees, mostly yew (Taxus baccata) and silver lime (Tilia argentea) were more common. In each stage of the gradient, we selected four sites, each at $\geq 50 \mathrm{~m}$ from the next, which were further subdivided into two patches, $20 \mathrm{~m}$ apart. A prey patch had five individual caterpillars placed $5 \mathrm{~m}$ apart, which amounts to a total of 115 caterpillars per sampling occasion (the only exception was one site in the urban forest fragment, which had only one prey patch instead of two) and 1426 caterpillars during the course of this experiment. This was repeated thirteen times at approximately fortnightly intervals from the end of April until the end of October 2010

\section{The dummy caterpillar method}

The artificial caterpillars were made of light green plasticine (Smeedi plus, V. nr. 776609, Denmark), using a modified garlic press, which produced a cylindrical shape (Howe et al., 2009), but $15 \mathrm{~mm}$ long and $3 \mathrm{~mm}$ thick as used by Tvardikova \& Novotny (2012). Green colour was chosen because predators react to aposematic warning colouration or defensive signals, such as
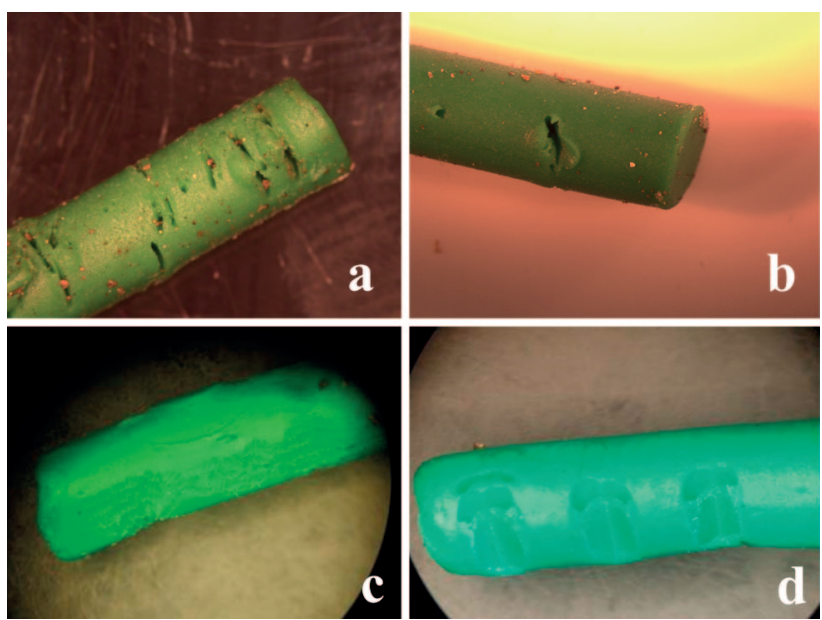

Fig. 1. Marks made by different predators on artificial caterpillars: "a" and "b" - chewing insects, "c" - ants, "d" - mammal. The pictures "a", "b" and "c" were taken using a digital colour microscope camera Leica DFC450 and "d" a Canon Ixus 60 camera.

eyespots (Hossie \& Sherratt, 2012). The 115 baits per sampling occasion were fixed to a suitable substrate lying on the ground (i.e. a dead leaf or dry branch) using super glue, exposed for $24 \mathrm{~h}$, after which they were examined in the field using a handheld magnifying glass $(12 \times)$. Chewing insects left characteristic mandible marks, ants numerous fine mandible marks, and small mammals their tooth marks (Fig. 1). Birds left characteristic beak marks (not illustrated). These marks were usually recognisable in the field, but in case of doubt, additional inspection was made in the laboratory using a stereomicroscope (Leica MS5, 0.63-4× magnification).

\section{Data analysis}

The study period was divided into three seasons (spring, summer and autumn) following the "quartile method" by Fazekas et al. (1997). The number of caterpillars collected in each season was comparable (491, 456 and 451, respectively). When a caterpillar was bitten by more than one type of predator, it was included as two independent predation events. Multiple marks by the same type of predator were categorised as a single predation event. A few ( $\mathrm{n}=28,2.0 \%$ ) caterpillars were lost; we were unable to identify the predator in $1.9 \%$ of the attacks. Due to their low values, data on predation by birds and unknown predators ( $\mathrm{n}$ $=30$ ) were not analysed as a separate category, resulting in the 1368 caterpillars included in the analysis. We tested the probability of survival along the urbanisation gradient using the site as a random component in a generalized linear mixed model, calculated using the package "Ime4" in R version 3.0.2 (R Core Team, 2013). As the random component did not affect the model, we reduced and adapted it to a logistic regression with "binomial" error distribution (link = logit). Subsequently we checked if outliers or collinearity affected the model using the package "car". Graphs were made using the "lattice" package (Sarkar, 2008).

\section{RESULTS}

\section{General results}

Of the 1398 artificial caterpillars, 50\% were attacked by predators. Chewing insects other than ants were responsible for $26.8 \%$ of the attacks on the artificial caterpillars. The other main predators were small mammals (with an 


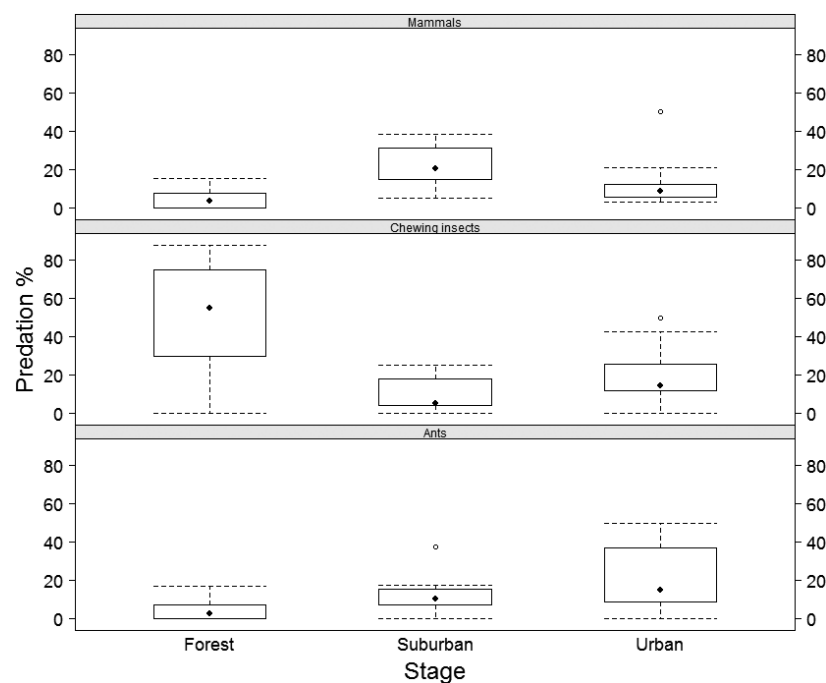

Fig. 2. Percentage predation recorded for the three main predator groups (ants, chewing insects, mammals) along an urbanisation gradient at Sorø, Denmark, 2010.

overall "predation rate" of $12.1 \%)$, ants (10.5\%), and birds $(0.43 \%)$.

\section{Predation along the urbanisation gradient}

There were different incidences in the predation of the artificial caterpillars by the different predators in the different stages of urbanisation (Fig. 2). In the forest, the caterpillars were mostly attacked by chewing insects $(52.1 \%)$; ants $(4.7 \%)$ and small mammals $(4.9 \%)$ had a low rate of attack. In the fragments of forest in suburban areas the most common marks found belonged to small mammals $(22.2 \%)$, followed by ants $(11.3 \%)$, and chewing insects $(10.1 \%)$. In the patches of forest in urban parks, marks inflicted by ants (16.4\%) and chewing insects (16.4\%) were more common than those made by small mammals $(8.1 \%)$. The seasonal incidence of predation by each of the predators in these different habitats differed (Fig. 3). The incidence of predation by chewing insects in the forest habitats increased from spring to autumn. That of small mammals in the suburban area was highest in summer, followed by a decline during autumn, and that of ants in the urban area highest in spring, after which it gradually declined. The level of urbanisation affected the probability of being attacked. Caterpillars were significantly more likely to be attacked in the forest than in either of the two other stages of urbanisation (odds ratio $=2.19,95 \% \mathrm{CI}=1.92-2.46$ and odds ratio $=1.93,95 \% \mathrm{CI}=1.68-2.18$, respectively,

TABLE 1. The effect of the level of urbanisation on the incidence of "predation" on artificial caterpillars at Sorø, Denmark, during spring-autumn of 2010, analysed using a generalized linear model. Incidence of predation in the forest and during autumn served as bases for comparison.

\begin{tabular}{lcccc}
\hline & Value & S.E. & Z value & Significance \\
\hline (Intercept) & -0.315 & 0.121 & -2.596 & 0.009 \\
Suburban & 0.670 & 0.131 & 5.104 & 0.000 \\
Urban & 0.801 & 0.137 & 5.848 & 0.000 \\
Spring & 0.225 & 0.134 & 1.682 & 0.093 \\
Summer & -0.481 & 0.136 & -3.536 & 0.000 \\
\hline
\end{tabular}

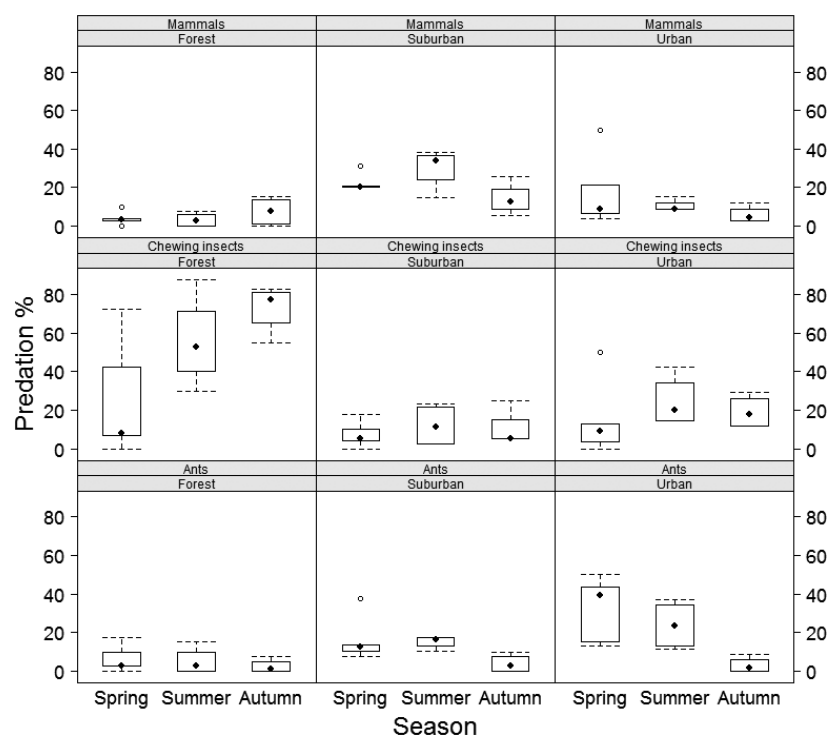

Fig. 3. Percentage predation recorded for the three main predator groups (ants, chewing insects, mammals) along an urbanisation gradient in three seasons at Sorø, Denmark, during 2010. The seasons are indicated on the horizontal axes and urbanisation stage inside each box.

$\mathrm{p}<0.001$ for both). There was no significant difference in predation pressure between the suburban vs. urban areas. The stage of urbanisation and season had a significant effect on caterpillar "survival" (Table 1), with higher values recorded in urban and suburban areas than in forest (value $=0.801, \mathrm{p}=0.000$ and value $=0.670, \mathrm{p}=0.000$, respectively).

\section{Predation during the season}

When the stage of urbanisation was not taken into consideration, the incidence of predation by each of the main types of predator varied little from spring to autumn (Fig. 4). Marks made by ants and mammals were usually more frequently recorded during spring and summer than in autumn, while for chewing insects, the frequency was higher

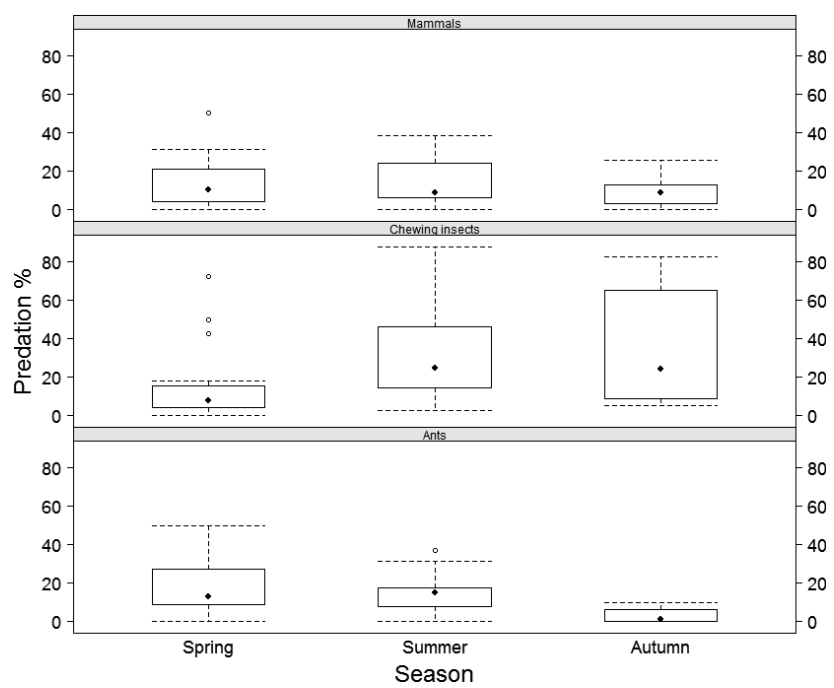

Fig. 4. Percentage predation recorded for the three main predator groups (ants, chewing insects, mammals) in the three seasons studied at Sorø, Denmark, 2010. 
TABLE 2. The number of artificial caterpillars attacked along the urbanisation gradient in three seasons by each category of predator: "ants", "ground-active insects" and "small mammals". Note that if an artificial caterpillar was attacked by more than one type of predator, it was counted in both categories.

\begin{tabular}{|c|c|c|c|c|c|}
\hline \multirow{2}{*}{ Habitat/season } & \multicolumn{3}{|c|}{ The number of artificial caterpillars attacked by } & \multirow{2}{*}{$\begin{array}{c}\text { No. of "unhurt" } \\
\text { artificial caterpillars }\end{array}$} & \multirow{2}{*}{$\begin{array}{l}\text { Total number of artificial } \\
\text { caterpillars exposed }\end{array}$} \\
\hline & Ants & Ground-active insects & Small mammals & & \\
\hline Forest & 23 & 256 & 24 & 199 & 491 \\
\hline Spring & 11 & 51 & 7 & 104 & 173 \\
\hline Summer & 8 & 89 & 5 & 64 & 166 \\
\hline Autumn & 4 & 116 & 12 & 31 & 163 \\
\hline Suburban & 55 & 49 & 108 & 276 & 486 \\
\hline Spring & 25 & 14 & 38 & 96 & 173 \\
\hline Summer & 24 & 19 & 48 & 67 & 158 \\
\hline Autumn & 6 & 16 & 22 & 113 & 157 \\
\hline Urban & 69 & 69 & 36 & 252 & 421 \\
\hline Spring & 32 & 10 & 14 & 91 & 147 \\
\hline Summer & 33 & 33 & 14 & 62 & 142 \\
\hline Autumn & 4 & 26 & 8 & 99 & 137 \\
\hline Grand Total & 147 & 374 & 168 & 727 & 1398 \\
\hline
\end{tabular}

in summer and autumn than spring (Table 2). However, when the stage of urbanisation was considered, the incidence of predation by the different predators during the year differed (Fig. 3). Survival was significantly affected by season, being lowest in summer (value $=-0.481, p=$ 0.000 ) and slightly higher in spring (value $=0.225, \mathrm{p}=$ 0.093) than in autumn.

\section{DISCUSSION}

Although there are records in the literature of the incidence of predation at ground level in a temperate region (Sipos et al., 2012), there is no information on the incidence of predation by different guilds of predators. Most of the studies carried out in the northern hemisphere using dummy prey have focused on predation by birds, with some studying defensive mechanisms such as countershading (Speed et al., 2005; Rowland et al., 2007). In our study we did not focus on any particular predator, but exploited the characteristic signs left by different predators in the malleable surface of the artificial caterpillars. The most common marks were those made by ground-active insects, ants and small mammals. The highest incidence of predation was by ground-active insects, as is recorded in other studies using artificial caterpillars (Faveri et al., 2008; Howe et al., 2009; Tvardikova \& Novotny, 2012). We believe that most of the chewing insect bites were made by ground beetles (Carabidae), the most common predators in the area (Elek \& Lövei, 2007). There were remarkably few attacks by birds, which are commonly recorded in tropical areas (Loiselle \& Farji-Brener, 2002; Howe et al., 2009). However, these studies, although using artificial caterpillars, were carried out in different habitats using different arrangements (artificial caterpillars were fixed to leaves and not on the ground), and therefore differences in the incidence of predation may reflect different hunting strategies (Martin, 1987). Nevertheless, in our study, risk of predation was generally high, and this may have influenced habitat selection by potential prey. It is unknown whether potential prey can assess this risk and whether it influences their behav- iour. We expected that due to the many different predators in forest areas, the highest incidence of predation would be recorded there, but this prediction was only partially supported. We found differences in the incidence of predation along the urbanisation gradient. In particular, the incidence of predation by ants and mammals was lowest in forest, despite the lower anthropogenic disturbance there, indicating that some predators may be favoured by human activities. However, like the trend in diversity and density of different taxonomical groups along urbanisation gradients (Magura et al., 2008), the effects of human disturbance on the incidence of predation may be related to the feeding or habitat preference of the guilds of predators studied. We recorded considerable differences in the incidence of predation when both season and stage of urbanisation were considered. This may indicate that abiotic factors differently influence the ecological services recorded in the different stages of urbanisation. Judged by the incidence of predation, suburban areas were favoured by small mammals in all the seasons studied. The same was true for chewing insects in forest and ants in urban areas, with the exception of spring and autumn, respectively. While the method is easy to use and useful in several situations (Howe et al., 2009), further refinements are needed. It is important to determine the optimal placement of the sentinel prey, and enlarge the catalogue of the different marks to identify a larger number of potential predators. For measuring ecological services in habitats subject to anthropogenic effects, it is important to control and quantify the conditions and intensity of these processes when assessing the effects of humans on nonhuman city dwellers, and develop countermeasures to preserve the irreplaceable services provided by biodiversity.

ACKNOWLEDGEMENTS. We thank the Sorø Akademi Stilftelse for permission to work on their land, J. Thomsen and A. Grube, for their assistance and support, A. Agüera, J. Halley and N. Holst for their comments. This is publication no. 9 of the Danglobe Project. Author contributions: study was designed by GL, with contributions by MF, AL; field work was performed by MF, $\mathrm{AL}$, and GL; data analysis MF, GL, AL, writing of the paper: MF, GL, with comments from AL. 


\section{REFERENCES}

Alaruikka D., Kotze D.J., Matveinen K. \& Niemelä J. 2002: Carabid beetle and spider assemblages along a forested urbanrural gradient in southern Finland. - J. Insect Conserv. 6: 195-206.

BRODIE E.D. 1993: Differential avoidance of coral snake banded patterns by free-ranging avian predators in Costa-Rica. - Evolution 47: 227-235.

Carpenter S.R., Mooney H.A., Agard J., Capistrano D., DeFries R.S., Diaz S., Dietz T., Duraiappah A.K., Oteng-Yeboah A. \& Pereira H.M. 2009: Science for managing ecosystem services: Beyond the Millennium Ecosystem Assessment. — Proc. Nat Acad. Sci. USA 106: 1305-1312.

ChACE J.F. \& WALSh J.J. 2006: Urban effects on native avifauna: a review. - Landsc. Urban Plann. 74: 46-69.

Churchfield S., Hollier J. \& Brown V. 1991: The effects of small mammal predators on grassland invertebrates, investigated by field exclosure experiment. — Oikos 60: 283-290.

DE Groot R.S., Wilson M.A. \& Boumans R.M.J. 2002: A typology for the classification, description and valuation of ecosystem functions, goods and services. - Ecol. Econ. 41: 393-408.

Elek Z. \& LöVer G. 2005: Ground beetles (Coleoptera, Carabidae) assemblages along an urbanisation gradient near Soro, Zealand, Denmark. — Entomol. Medd. 73: 115-121.

Elek Z. \& LöVei G.L. 2007: Patterns in ground beetle (Coleoptera: Carabidae) assemblages along an urbanisation gradient in Denmark. - Acta Oecol. 32: 104-111.

FAVERI S.B., VASCONCELOS H.L. \& DiRzo R. 2008: Effects of Amazonian forest fragmentation on the interaction between plants, insect herbivores, and their natural enemies. - J. Trop. Ecol. 24: 57-64.

Fazekas J., Kadar F., Sarospataki M. \& LöVei G.L. 1997: Seasonal activity, age structure and egg production of the ground beetle Anisodactylus signatus (Caleoptera: Carabidae) in Hungary. - Eur. J. Entomol. 94: 473-484.

GRAY J.S. 1989: Effects of environmental-stress on species rich assemblages. - Biol. J. Linn. Soc. 37: 19-32.

Hawes C., Stewart A. \& Evans H. 2002: The impact of wood ants (Formica rufa) on the distribution and abundance of ground beetles (Coleoptera: Carabidae) in a Scots pine plantation. Oecologia 131: 612-619.

Hawes C., Evans H.F. \& Stewart A.J. 2013: Interference competition, not predation, explains the negative association between wood ants (Formica rufa) and abundance of ground beetles (Coleoptera: Carabidae). - Ecol. Entomol. 38: 315-322.

Hilty J. \& Merenlender A. 2000: Faunal indicator taxa selection for monitoring ecosystem health. - Biol. Conserv. 92: 185-197.

Horváth R., Magura T. \& Tóthmérész B. 2012: Ignoring ecological demands masks the real effect of urbanization: a case study of ground-dwelling spiders along a rural-urban gradient in a lowland forest in Hungary. - Ecol. Res. 27: 1069-1077.

Hossie T.J. \& SherRatT T.N. 2012: Eyespots interact with body colour to protect caterpillar-like prey from avian predators. Anim. Behav. 84: 167-173.

Howe A. \& EngaARD M. 2006: Ground Beetles and Urbanisation. BSc Thesis, Roskilde University, Denmark, 62 pp.

Howe A., Lövei G.L. \& Nachman G. 2009: Dummy caterpillars as a simple method to assess predation rates on invertebrates in a tropical agroecosystem. - Entomol. Exp. Appl. 131: 325-329.

KidD N.A. \& Jervis M.A. 2007: Population dynamics. In Jervis M.A. (ed.): Insects as Natural Enemies: A Practical Perspective. Springer, Dordrecht, pp. 435-523.
Isbell F., Calcagno V., Hector A., Connolly J., Harpole W.S., Reich P.B., Scherer-Lorenzen M., Schmid B., Tilman D., van Ruijven J., Weigelt A., Wilsey B.J., Zavaleta E.S. \& Loreau M. 2011: High plant diversity is needed to maintain ecosystem services. - Nature 477: 199-202.

Layke C., Mapendembe A., Brown C., Walpole M. \& Winn J. 2012: Indicators from the global and sub-global Millennium Ecosystem Assessments: An analysis and next steps. - Ecol. Indic. 17: 77-87.

Liss K.N., Mitchell M.G., MacDonald G.K., Mahajan S.L., Мéthot J., Jacob A.L., Maguire D.Y., Metson G.V.S., Ziter C. \& DANCosE K. 2013: Variability in ecosystem service measurement: a pollination service case study. - Front. Ecol. Environ. 11: 414-422.

Loiselle B.A. \& FARJI-Brener A.G. 2002: What's up? An experimental comparison of predation levels between canopy and understory in a tropical wet forest. - Biotropica 34: 327-330.

LÖVEI G.L. \& SunDERLAND K.D. 1996: Ecology and behavior of ground beetles (Coleoptera: Carabidae). - Annu. Rev. Entomol. 41: 231-256.

Magura T., Tóthmérész B., Hornung E. \& Horváth R. 2008: Urbanization and ground-dwelling invertebrates. In Wagner L.N. (ed.) Urbanization: 21st Century Issues and Challenges. Nova Science Publishers, New York, pp. 213-225.

Magura T., Lövei G.L. \& TóthméRÉsz B. 2010: Does urbanization decrease diversity in ground beetle (Carabidae) assemblages? - Global Ecol. Biogeogr. 19: 16-26.

MARTIN T.E. 1987: Artificial nest experiments: effects of nest appearance and type of predator. - The Condor 89: 925-928.

Mäntylä E., Alessio G.A., Blande J.D., Heijari J., Holopainen J.K., Laaksonen T., Piirtola P. \& Klemola T. 2008: From plants to birds: higher avian predation rates in trees responding to insect herbivory. - PlosOne 3: e2832.

McKinNeY M.L. 2002: Urbanization, biodiversity, and conservation. - Bioscience 52: 883-890.

Millennium Ecosystem Assessment 2005: Ecosystems and Human Well-being: Synthesis. Island Press, Washington, DC, 155 $\mathrm{pp}$

O’Neal M.E., Zontek E.L., Szendrei Z., Landis D.A. \& Isaacs R. 2005: Ground predator abundance affects prey removal in highbush blueberry (Vaccinium corymbosum) fields and can be altered by aisle ground covers. - BioControl 50: 205-222.

Östman O., Eквом B. \& Bengtsson J. 2001: Landscape heterogeneity and farming practice influence biological control. Basic Appl. Ecol. 2: 365-371.

Parmenter R.R. \& MacMahon J.A. 1988: Factors influencing species composition and population sizes in a ground beetle community (Carabidae): predation by rodents. - Oikos 52: 350-356.

Posa M.R.C., SodHI N.S. \& KoH L.P. 2007: Predation on artificial nests and caterpillar models across a disturbance gradient in Subic Bay, Philippines. - J. Trop. Ecol. 23: 27-33.

R CORE TEAm 2013: R: A Language and Environment for Statistical Computing. R Foundation for Statistical Computing, Vienna, Austria. URL http://www.R-project.org/

Rowe R.L., Goulson D., Doncaster C.P., Clarke D.J., Taylor G. \& HANLEY M.E. 2013: Evaluating ecosystem processes in willow short rotation coppice bioenergy plantations. - Glob. Change Biol. Bioen. 5: 257-266.

Rowland H.M., Speed M.P., Ruxton G.D., Edmunds M., Stevens M. \& HARVEY I.F. 2007: Countershading enhances cryptic protection: an experiment with wild birds and artificial prey. Anim. Behav. 74: 1249-1258.

SARKAR D. 2008: Lattice: Multivariate Data Visualization with $R$. Springer, New York, 268 pp. 
Siros J., Drozdova M. \& Drozd P. 2012: Effect of canopy openness on the pressure of predatory arthropods and birds on epigeic insects. - Centr. Eur. J. Biol. 7: 1021-1029.

Speed M.P., Kelly D.J., Davidson A.M. \& Ruxton G.D. 2005: Countershading enhances crypsis with some bird species but not others. - Behav. Ecol. 16: 327-334.

TVardikova K. \& Novotny V. 2012: Predation on exposed and leaf-rolling artificial caterpillars in tropical forests of Papua New Guinea. - J. Trop. Ecol. 28: 331-341.
Wilson A.P., Hough-Goldstein J.A., Vangessel M.J. \& Pesek J.D. 2004: Effects of varying weed communities in corn on European corn borer, Ostrinia nubilalis (Hubner) (Lepidoptera: Crambidae), oviposition, and egg mass predation. - Environ. Entomol. 33: 320-327.

Received January 31, 2014; revised and accepted June 12, 2014 Prepublished online September 12, 2014 